\title{
Morphology and Literature
}

\begin{abstract}
This essay offers a broad overview of the main critical questions concerning the concept of morphology in literary theory. It sets out by exploring the origins of morphology in classical thought and in Goethe's writings, and by discussing its affinity with the German concept of Bildung (and its embodiment in the Bildungsroman genre). Then, it briefly examines the role of morphology in the work of some key twentieth century thinkers, discussing Aby Warburg's approach to art history, Andre Jolles' theory of the 'simple forms', the anti-historicist elements in the thought of Walter Benjamin and then Carlo Ginzburg's epistemological reflections (with their roots in Wittgenstein's thought). Finally, it goes back to the aesthetic theory of the Romantics - as exemplified by Schlegel's fragments from the Athenaeum - and examines the legacy of their critical approach in the current interdisciplinary discussion on forms and their representation.
\end{abstract}

It would take the etymological wisdom of Leo Spitzer, as well as years of study in the most diverse research fields, to reconstruct the boundaries of that complex 'semantic family' of keywords pertaining to the morphological study of literature. ${ }^{1}$ I shall therefore confine myself to a few words - Bildung, comparison, correspondence, nature, topos and anachronism - and some of the fundamental components of their historical stratification. ${ }^{2}$

Note: I am indebted to Luca Giovannini for his careful and invaluable work on this essay and to Giuliana Ferreccio for her thoughtful feedback.

1 The study of morphology in literature traces back its roots to the work of the Russian Formalists (Eikhenbaum, Shklovsky, Tynyanov, Jakobson, Propp) and to canonical studies such as Ernst R. Curtius' Europäische Literatur und Lateinisches Mittelalter (1948), Northop Frye's Anatomy of Criticism (1957) or, more recently, Alistair Fowler's Kinds of Literature: An Introduction to the Theory of Genres and Modes (1982).

2 The recent conference Forms, History, Narrations, Big Data: Morphology and Historical Sequence, which was held in Turin between the $21^{\text {st }}$ and $22^{\text {nd }}$ November 2019, aimed to review the state of recent scholarship in morphological studies and survey the different epistemic models that, consciously or not, are employed today to explain the new frontiers of narration and visual representation. Conference acts will be published in an upcoming issue of Cosmo - Comparative Studies in Modernism (https://www.ojs.unito.it/index.php/COSMO/index)

Ә OpenAccess. () 2021 Roberto Gilodi, published by De Gruyter. (cc))BY-NC-ND This work is licensed under the Creative Commons Attribution-NonCommercial-NoDerivatives 4.0 International License. https://doi.org/10.1515/9783110674194-008 
Morphology is a matter of perspective, i.e. a particular point of view from which one can observe known cultural phenomena and their place in history. Upon a closer look, it is actually a double, simultaneous point of view, since nature could be viewed from the observatory of culture, and culture from the observatory of nature.

The following remarks will focus in particular on three main topics: the crucial relationship between the concepts of 'morphology' and 'Bildung', the morphological thought of a series of twentieth century thinkers (such as Aby Warburg and Walter Benjamin) and the contributions of Romantic authors (such as Friedrich Schlegel) to the debate.

\section{Morphology and Bildung}

Morphology, literally 'the study of forms', has historically been opposed to the study of an evolution that takes place over time (Curtius 2013, 391ff.), even though morphology itself has undergone its own historical transformations. Its roots lie in Greek antiquity, where the notion of 'form', and in particular that of 'inner form', was at the centre of philosophical research, as Jean-Pierre Vernant explains:

Trois traits - caractère profane et positif, notion d'un ordre de la nature abstraitement conçu et fondé sur des rapports de stricte égalité, vision géométrique d'un univers situé dans un espace homogène et symétrique - [...] définissent solidairement ce que la rationalité grecque, dans sa forme et dans son contenu, comporte de neuf par rapport au passé et d'original par comparaison avec les civilisations du Proche-Orient que les Grecs ont pu connaître (Vernant 2007, 156).

Classical Greek thought is entirely developed around the notion of form, investigated both as a separate principle (the notion of idea in the dialogues of Plato's maturity), and as an immanent structure of reality, tasked with justifying its conformation and purpose (particularly in living beings, as in Aristotle's Physics). ${ }^{3}$

Among several turning points that have marked the evolution of the concept of morphology, the most widely known is certainly the one linked to Goethe and his studies on the forms of nature. ${ }^{4}$ According to Goethe, nature was indeed not

3 On the concept of form in Plato and Aristotle see for example Fronterotta 2014, 127-138, and Gasser 2015. Older but still useful contributions are Theodor W. Adorno's lecture on "Form and Matter" (Adorno 2000, 60-68) and John E. Boodin's “The Discovery of Form” (1943, 177-192). 4 Goethe's writings represent one of the main sources for the $19^{\text {th }}$ and $20^{\text {th }}$ century genealogies of morphology and were collected in an influential edition by Wilhelm Troll (Troll 1926). A recent 
only the physis but also the essence of artistic forms, insofar as they both take part in the rational and regular mechanisms which govern the formation (Bildung) of natural objects - it should be borne in mind that Goethe's Bildung is a concept that refers not only to the moral world, but also to the natural and artistic worlds. ${ }^{5}$

In contrast to its more widespread meaning, Goethe's understanding of Bildung does not involve only the individual and his 'ethical becoming' or moral development: for him, this term also points at the formation of symbolic systems that are distinctive of cultural geographies such as, first and foremost, the linguistic system. After all, as Herder stated in his 1772 essay on the origin of language (Herder 1772), words originate from nature, and their formation and transformation remain indebted to its rules.

As recalled by Curtius, Goethe in his last years dedicated himself to the study of the metaphorical expression in a comparative perspective; to be more precise, "[t]he idiosyncratic nature of poetic figurative language was forced upon Goethe's attention in his study of Oriental poetry" (Curtius 2013, 302). This critical stance, according to Curtius, is best exemplified by a quote from the Noten und Abhandlungen to the West-Östlicher Divan $(1819,1827)$, taken from the section Orientalischer Poesie Urelemente:

...und beachtet [man] alles übrige Sichtbare: Berg und Wüste, Felsen und Ebene, Bäume, Kräuter, Blumen, Fluß und Meer und das vielgestirnte Firmament, so findet man, daß dem Orientalen bei allem alles einfällt, so daß er, übers Kreuz das Fernste zu verknüpfen gewohnt, durch die geringste Buchstaben- und Silbenbiegung Widersprechendes auseinander herzuleiten kein Bedenken trägt. Hier sieht man, daß die Sprache schon an und für sich

assessment of their influence is offered in Morphologie und Moderne. Goethes "anschauliches" Denken in den Geistes- und Kulturwissenschaften seit 1800 (Maatsch 2014).

5 The concept of Bildung in Goethe is strictly related to that of Gestalt ("form"). This is illustrated by the following passage, which serves as an introduction to Zur Morphologie (1807): "Der Deutsche hat für den Komplex des Daseins eines wirklichen Wesens das Wort Gestalt. Er abstrahiert bei diesem Ausdruck von dem Beweglichen, er nimmt an, daß ein Zusammengehöriges festgestellt, abgeschlossen und in seinem Charakter fixiert sei. Betrachten wir aber alle Gestalten, besonders die organischen, so enden wir, daß nirgend ein Bestehendes, nirgend ein Ruhendes, ein Abgeschlossenes vorkommt, sondern daß vielmehr alles in einer steten Bewegung schwanke. Daher unsere Sprache das Wort Bildung sowohl von dem Hervorgebrachten, als von dem Hervorgebrachtwerdenden gehörig genug zu brauchen pflegt. Wollen wir also eine Morphologie einleiten, so dürfen wir nicht von Gestalt sprechen; sondern, wenn wir das Wort brauchen, uns allenfalls dabei nur die Idee, den Begriff oder ein in der Erfahrung nur für den Augenblick Festgehaltenes denken. Das Gebildete wird sogleich wieder umgebildet, und wir haben uns, wenn wir einigermaßen zum lebendigen Anschaun der Natur gelangen wollen, selbst so beweglich und bildsam zu erhalten, nach dem Beispiele mit dem sie uns vorgeht” (Goethe 1987, 382). 
produktiv ist, und zwar, insofern sie dem Gedanken entgegenkommt, rednerisch, insofern sie der Einbildungskraft zusagt, poetisch (Goethe 1988, 222). ${ }^{6}$

Commenting on this passage, Curtius conjectures that Goethe is here outlining "the program for an investigation of figurative language in poetry. It would have to extend to all literatures, ascertain their peculiarities, and present the facts in orderly fashion. Thus, it would have to be at once general and comparative" (Curtius 2013, 303). Indeed, the study of Oriental poetry is part and parcel of Goethe's more general project of a Weltliteratur, which is first conceived as a system of universal literary comparison - whose constituents are not macro-themes, as believed in some contemporary departments of comparative literature, but metaphors, tropes and topoi, i.e. the basic and original units of poetic construction (Koch 2002; Strich 1957).

This linguistic game of infinite correspondences that Goethe recognizes in Oriental poetry derives indeed from a gnoseology based on the comparison of the seemingly incomparable, which Goethe had developed through his studies on plant morphology and comparative anatomy. ${ }^{7}$

According to Schelling, the method of the 'new philosophy' was based upon such a gnoseology. In a lecture on the origin of language (Vorbemerkungen zu der Frage über den Ursprung der Sprache, presented to the Bayerische Akademie der Wissenschaften in München in 1850) he argued:

Wenn unsere Zeit in Bezug auf die Frage zurückhaltender geworden, oder wenigstens in die eigentliche Tiefe derselben noch nicht eingegangen ist, so darf man dies vielleicht als Folge des Umstandes betrachten, den wir als die erfreulichste Folge der neueren Philosophie ansehen, daß die großen Gegenstände fernerhin nicht mehr wie ehemals capitelweis, abgeschnitten vom allgemeinen Zusammenhang abgehandelt werden können - und die Philosophie entweder sich selbst aufgeben oder sich bestreben muß, in der That jenes Webermeisterstück zu seyn, von dem Goethe spricht, wo ein Tritt tausend Verbindungen schlägt (Schelling 1989, 505-506; cf. Hennigfeld 1984, 16-29; Whistler 2013).

Therefore philosophy, not unlike literature, appears to be better conceived as an opus magnum, which that betrays its affinities with the hermetic tradition and with alchemy's pursuit of the universal transformation of matter. This further genealogy should probably be further explored from the perspective of the last Goethe, but such an investigation goes beyond the scope of this chapter.

6 On the West-östlicher Divan and its language see Lemmel 1987, and Schwieder 2001.

7 See for example Die Metamorphose der Pflanzen (1790) - not to be confused with the 1798 elegy with the same name - or Dem Menschen wie den Tieren ist ein Zwischenknochen der Obern Kinnlade zuzuschreiben (1786). 
It is worth returning instead to the meanings of the word Bildung, a word which is central not only in Goethe but also in the narrative tradition of the so-called Bildungsroman. The word originated in medieval theology and was particularly relevant in the mystical doctrines of Meister Eckhart (1260 - 1328), where it is employed in relation to the doctrine of the imago dei and the Bildwerdung des Menschen, i.e. the becoming image of mankind. ${ }^{8}$

On an etymological level, the verb bilden - 'to give shape' - does indeed relate to Bild, 'image': Bildung is therefore being formed in the image of God. Therefore, every product of bilden is a nachbilden, an imitation; bilden always implies both an inner and an iconic dimension. For his part, Herder regarded the Bildung as the Menschwerdung des Menschen. This effective phrasing, which reveals an affinity with Vico's thought, implies a reversal of the mystical perspective: the 'conquest of mankinde's humanity' (Herder) can be understood as the secularized version of 'becoming the image of God' (Vico 2020; Herder 1774; Gaier 2004, 104-115; Forster 2012, 75-89). ${ }^{9}$ Both paths - the 'horizontal' one of the mundane progression and the 'transcendent' one of the mystical ascension - lead to the conquest of a wholeness within which the dissonances of human nature are composed in harmony.

On this journey towards the full acquisition of a moral identity, humans meet the image of the divine which they strive to imitate; divinity, though, remains unreachable, and even secularized moral perfection soon reveals itself to be a utopia. This is illustrated by the German Bildungsromane of the second half of the eighteenth century: ${ }^{10}$ after Wieland's Agathon (1766), which was still animated by a sort of harmonizing tension, where mankind's physis finds its fulfilment (Vollendung) in moral completeness, the crisis of the Bildung process became evident in works like Moritz' Anton Reiser (1790) and reached its apex with the 'broken teleology' (Sorg 1983) of Goethe's Wilhelm Meister (1795-96).

It is, of course, the outcome of an internal conflict within the hero himself for he is almost always a he in these works - between what he is by nature and what he should be, and the process that fills this gap is precisely the Bildung. It is therefore interesting to note how this term is poised between religious doctrine

8 On Eckhart's notion of Bildung see Hellmeier 2016, 67-82, and Gennari 2014, 131-149. On the evolution of the concept of Bildung see Bilstein 2004, 415-432, and Horlacher 2017.

9 See also the chapter on Herder's analogical thought by L. Follesa in this volume [Anm. d.H.]. 10 Even a minimal bibliography on the Bildungsroman - a critical term introduced by Karl Morgenstern in the early nineteenth century, and later popularised by Wilhelm Dilthey - would take pages; among several insightful contributions, see at least Bakhtin 1986, 10 -59; Moretti 1987; and Graham 2019. On the specific German milieu see Jacobs-Krause 1989; Selbmann 1994; Mayer 1992; and Swales 2015. 
and moral formation, and how already in Erasmus' pedagogy it had come to signify the construction of a worldly identity. ${ }^{11}$

Further on, in the secularized Enlightenment thought, the Bildung went on to embody the construction of a political subject, i.e. the man or woman of the new polis, whose personal aspirations to happiness mirror, but in many cases oppose, those of the community. ${ }^{12}$ Thus, when this concept reached the Goethezeit, it was already designating a layered meaning in which form and image are not static realities, but dynamic entities, subject to the rules of evolution of human nature.

It is no coincidence that Wieland, within the first few pages of Agathon, promptly declares his debt to nature. Following Erasmus, the author argues that virtue and Bildung cannot be separated from nature, and thus says in his Vorbericht:

Die Wahrheit, welche von einem Werke, wie dasjenige [...], gefodert werden kann und soll, bestehet darin, daß alles mit dem Lauf der Welt übereinstimme, daß die Character nicht willkürlich, und bloß nach der Phantasie, oder den Absichten des Verfassers gebildet, sondern aus dem unerschöpflichen Vorrat der Natur selbst hergenommen (Wieland 1981, 5).

Within Goethe's reflections on morphology another aspect which emerges relates to the concept of time and, more precisely, to the overcoming of the chronological dimension, i.e. the temporal succession. The reference here is to a littleknown text, Die Theilnahme Goethe's an Manzoni (1827), in which he examines the grounds for the success of Alessandro Manzoni's Adelchi and concludes that the essence of the drama, and the reason of its success, is its anachronism. Indeed, the author closes his argument by stating peremptorily that "alle Poesie eigentlich in Anachronismen verkehre", since "[d]ie Ilias wie die Odyssee, die sämmtlichen Tragiker und was uns von wahrer Poesie übrig geblieben ist, lebt und athmet nur in Anachronismen” (Goethe 1999, 806).

Goethe sees anachronism as a gesture of appropriation, assimilation, integration of something into the present - a blatantly anti-historical gesture, if we look at it from the perspective of nineteenth-century Historicism, whose

11 On Erasmus' pedagogy see Stupperich 2017, chapter IV ("Im Bereich der Bildung und Erziehung”), and Heine 2016. A comprehensive, albeit a bit dated study is that by Woodward 2013 (first ed. 1904).

12 Franco Moretti considers the utopia of the perfect reconciliation between the individual Streben and the collective ratio as the distinctive feature of the Bildungsroman. In Moretti's words: "The classical Bildungsroman - with its perfect, and perfectly meaningful conclusion - is still on this side of the great symbolic divide. Better yet, it acts like a hinge between the two worlds: here youth is already full, and maturity not yet drained" (Franco Moretti, The Way of the World, 28). 
idea of history was characterized by philological accuracy and documentary precision. If, therefore, true poetry is anachronistic, it must free itself from its contingency, from its temporal constraints, thus becoming an ideal in which people of different eras can recognize themselves; accordingly, Goethe praises the artist's freedom to invent possible worlds without worrying about historical consistency.

\section{Key Figures in Morphological Thought, from Warburg to Benjamin}

The heritage of Goethe's thought has informed several twentieth-century critical stances on the relationship between history and morphology. Among the most relevant ones, one may cite the approach by Aby Warburg and his followers to art history, the morphological reflections of Vladimir Propp and André Jolles and eventually the anti-historicistic elements in the thought of Walter Benjamin (Warburg 2018a und 2018b; Propp 1968, 1984, and 1985; Jolles 1930; Benjamin 1991). More recently, the morphological theme has also been central in the scientific investigations and in the epistemological research of scholars examining the relationship between invariant forms and history or visual arts, such as Carlo Ginzburg, Salvatore Settis, Maria Luisa Catoni etc. (Settis 1999; Catoni et al. 2013). I shall confine myself here to a brief overview of the main topics of interest.

Carlo Ginzburg has raised the problem of the relationship between morphology and history in his Myths, Emblems and the Historical Method (1990) - whose Italian subtitle (Morfologia e storia) explicitly names these two central elements. In the book, he explains how he became aware that his method "was much more morphological than historical" because he was "collecting myths and beliefs from different cultural contexts on the basis of formal affinities." He realized that the relevant elements of his research were not related to a specific historical period or a specific place. Indeed, beyond the apparent differences, there were common forms which people living in different cultures shared in terms of narrations and beliefs. Ginzburg's model was Propp, who was able to combine a morphological approach with an historical one. In other words, Propp's investigation of the popular narrative heritage was based on a distinction between the "morphology of the folktale" and "the historical roots of fairy tales". The heuristically fruitful method by Propp offered Ginzburg the model for an investigation proceeding in two phases: "In my plan, the work of classification should consti- 
tute a preliminary phase, meant to reconstruct a series of phenomena which I would like to analyse historically"(Ginzburg 2013, xii).

Ginzburg mentions an interesting passage in Wittgenstein's Notes on Frazer's Golden Bough "where Wittgenstein juxtaposes two ways of presenting material, one synoptic and achronic, the other based on a hypothesis of a chronological development, emphasizing the superiority of the former" (Ginzburg 2013, xii). Wittgenstein, like Propp, is also referring to the morphological thinking of Goethe. The passage in which he explains it, is the following:

Die historische Erklärung, die Erklärung als eine Hypothese der Entwicklung ist nur eine Art der Zusammenfassung der Daten - ihrer Synopsis. Es ist ebensowohl möglich, die Daten in ihrer Beziehung zu einander zu sehen und in ein allgemeines Bild zusammenzufassen, ohne es in Form einer Hypothese über die zeitliche Entwicklung zu machen [...]. "Und so deutet das Chor auf ein geheimes Gesetz" möchte man zu der Frazer'schen Tatsachensammlung sagen. Dieses Gesetz, diese Idee, kann ich nun durch eine Entwicklungshypothese darstellen oder auch, analog dem Schema einer Pflanze, durch das Schema einer religiösen Zeremonie, oder aber durch die Gruppierung des Tatsachenmaterials allein, in einer 'übersichtlichen' Darstellung [...]. Diese übersichtliche Darstellung vermittelt das Verständnis, welches eben darin besteht, daß wir die "Zusammenhänge sehen". Daher die Wichtigkeit des Findens von Zwischengliedern (Wittgenstein - Rhees 1967, 241).

The key point in this quote is the übersichtliche Darstellung, which makes evident the secret law of nature - a formula which Wittgenstein borrows from Goethe's work Die Metamorphose der Pflanzen (1798). ${ }^{13}$ In this elegy the choir alludes to the mystery of unity within multiplicity in nature: in the infinite variety of natural forms one can indeed observe an original common pattern. Thus, evolution and transformation do not follow an external law of development, nor do they obey historical contingencies, but are rather already contained within things, just as the growth of a tree is already contained in its seed. ${ }^{14}$

As for Warburg, I would simply say that his research began with the rejection of the "Apollonian antiquity of the classicists" to turn to an "age steeped in Dionysian pathos" (Ginzburg 2013, 20). ${ }^{15}$ Furthermore, we have the testimony of

13 "Alle Gestalten sind ähnlich, und keine gleichet der andern, / Und so deutet das Chor auf ein geheimes Gesetz, / Auf ein heiliges Rätsel” (Goethe 1988, 206).

14 On Wittgenstein, Frazer and the Goethian idea of morphology see: Sbisà 1984, 33-40. See in particular this remark: "The evolutionary hypothesis remains for Wittgenstein a 'disguise of a formal connection' of those intermediate rings that connect the different forms of anthropological fact”. See also on Wittgenstein and Goethe the remarkable essay by Schulte 1982, 99-124. 15 On the influence of Goethe's morphological thought on Warburg see Brusotti - Mainsberger 2017, 209-238. 
Gertrud Bing, former student and later director of the Warburg Institute, who identified the main research interests of her mentor as follows:

The role of the coining of images as a process of civilization and the changing relations between the images of art and of language. All the other elements in his inquiries which are now thought to be characteristic, his interest in iconography, his focus on the Nachleben der Antike, are much more means to an end than ends in themselves (Bing 1965, 302).

These elements reflect Warburg's long-lasting commitment to the study of the kulturwissenschaftliche Bildgeschichte ("the history of images as the object of the history of culture") as a proxy for an 'historical psychology of human expression'. This anthropological root of Warburg's research, deeply influenced by Charles Darwin's The Expression of Emotions in Humans and Animals (1872), is actually common to all morphological studies, although in different gradations.

It is evident, for example, in Vladimir Propp, who studied the form of fairy tales, and in André Jolles, who studied elementary literary expressions (sagas, myths, puzzles, fairy tales, legends) and saw them as forms of a culture to be understood as Bildung. The language is for Jolles a 'productive energy', and in the introduction to his Simple Forms (1930) he states:

\footnotetext{
Sprache schafft Gestalt, indem Sprache - wir benützen das Wort in der eigentlichen Bedeutung - dichtet [...]. Da, wo Sprache dichtet, pflegen wir zu sagen, daß Literatur entsteht. Damit haben wir einen Übergang gefunden, den wir anfangs suchten. Und wir wissen, daß Sprache als um-ordnende Arbeit hier unmittelbar zur Literatur führt, auch wenn diese Literatur nicht von einem bestimmten Dichter stammt oder in einem bestimmten Kunstwerk festgelegt ist. Und dann sehen wir zugleich, wie durch die Sprache oder durch die Literatur etwas ergriffen, verändert und erneuert wird, was um ein kühnes Wort zu gebrauchen in der Natur gegeben war (Jolles 1968, 17-18).
}

After this passage, a little further down in Jolles' text, one finds an interesting statement, which bears some resemblance to Benjamin's idea of an original foundation for language and forms: "Auslegend und einengend dringt [der Mensch] zu den Grundformen durch" (Jolles 1968, 22). What is proposed here is actually a genealogical hermeneutics in which the text is projected towards its remote origin, where the Bildung process began.

To Jolles' epistemic model I would like to juxtapose the one proposed by Walter Benjamin in a letter (dated December 9, 1923) to his friend Florens Christian Rang:

Die spezifische Geschichtlichkeit von Kunstwerken ist ebenfalls eine solche, welche sich nicht in 'Kunstgeschichte' sondern nur in Interpretation erschließt. Es treten nämlich in der Interpretation Zusammenhänge von Kunstwerken untereinander auf, welche zeitlos 
und dennoch nicht ohne historischen Belang sind. Dieselben Gewalten nämlich, welche in der Welt der Offenbarung (und das ist die Geschichte) explosiv und extensiv zeitlich werden, treten in der Welt der Verschlossenheit (und das ist die der Natur und der Kunstwerke) intensiv hervor (Benjamin 1978, 322).

By making these distinctions, Benjamin operates a reversal of the traditional assumptions regarding the construction of a work of art. According to him, any cultural artefact, such as a literary work, consists of elements that participate in a systematic unity that transcends not only the horizons of its time but also the organizational categories on which poetics are based - an example being the so-called Literaturwissenschaft, or "science of literature", which arose in the German academic world during the twentieth century.

Such systematic unity is based on a network of unpredictable affinities in which figures, stories, voices, postures and stylistic traits resurface after centuries, sometimes after millennia, thus escaping any possible historical conditioning but rather apparently obeying to a combinatorial need, which only a hermeneutic focused on the value of detail could understand.

Currently, the problem of forms, for example in narrative, is increasingly investigated through paradigms which did not originate in literary theory, but rather come from the observation of nature and human behaviour. Accordingly, literature and the visual arts are often faced with other modes of expression, seen through their origins in human physiology and its evolution: literary anthropology and in particular the so-called "biopoetics" study these relationships. Among the many studies on biopoetics see Carroll 1995, and 2012; Cooke 2001, 1-8; and Cometa 2011.

\section{The Romantics' Contribution to Morphological Thought}

Several scientific approaches to the problem of forms and their representations originated from the typically 'modern' encounter between Enlightenment encyclopaedic thought and critical stances of early German Romanticism. On the one hand, there was the need for a systematic definition of the arts, which probably found its maximum expression in Charles Batteaux' Les Beaux-Arts réduits à un même principe (1746); on the other hand, the essence or truth of the Modernity - in the words of Friedrich Schlegel, das wesentlich Moderne - was identified with chaos. In his Gespräch über die Poesie (1800) Schlegel writes: 
Die höchste Schönheit, ja die höchste Ordnung ist denn doch nur die des Chaos, nämlich eines solchen, welches nur auf die Berührung der Liebe wartet, um sich zu einer harmonischen Welt zu entfalten, eines solchen wie es auch die alte Mythologie und Poesie war. Denn Mythologie und Poesie, beide sind eins und unzertrennlich. Alle Gedichte des Altertums schließen sich eines an das andre, bis sich aus immer größern Massen und Gliedern das Ganze bildet; alles greift in einander, und überall ist ein und derselbe Geist nur anders ausgedrückt. Und so ist es wahrlich kein leeres Bild, zu sagen: die alte Poesie sei ein einziges, unteilbares, vollendetes Gedicht. Warum sollte nicht wieder von neuem werden, was schon gewesen ist? Auf eine andre Weise versteht sich. Und warum nicht auf eine schönere, größere? (Schlegel 1967, 312).

The Jena Romanticism invented a poetic utopia that Schlegel called 'novel' or 'romantic novel': a dynamic literary artefact capable of aggregating and merging the most disparate formal elements of the poetic art. The result was a productive interaction of different forms of expression and their legitimation on an historical and aesthetical level: poetic modernity, at its beginnings, became characterized by the drive to overcome the rigid divisions between literary and artistic styles and genres. An effective expression of this goal is to be found in the fragments published by Schlegel in the Athenaeum (1798-1800).

I will cite excerpts of two of them, starting with the well-known fragment 116:

Die romantische Poesie ist eine progressive Universalpoesie. Ihre Bestimmung ist nicht bloß, alle getrennte Gattungen der Poesie wieder zu vereinigen, und die Poesie mit der Philosophie und Rhetorik in Berührung zu setzen. "Sie will, und soll auch Poesie und Prosa, Genialität und Kritik, Kunstpoesie und Naturpoesie bald mischen, bald verschmelzen, die Poesie lebendig und gesellig, und das Leben und die Gesellschaft poetisch machen, den Witz poetisieren, und die Formen der Kunst mit gediegnem Bildungsstoff jeder Art anfüllen und sättigen, und durch die Schwingungen des Humors beseelen (Schlegel 1967, 181-182).

This idea of a syncretic poetical artefact has platonic roots: it has to do with the idea of the origin as Chaos. Nevertheless, chaos is strictly related with order and, for the Jena romantic school, chaos is a necessary condition to differentiate between the single elements, to measure them against one another, and to recompose a cosmos in systemic unity. This syncretic process fully englobes within itself the idea of Bildung, because, in Schlegel's words: "Sie ist der höchsten und der allseitigsten Bildung fähig; nicht bloß von innen heraus, sondern auch von außen hinein; indem sie jedem, was ein Ganzes in ihren Produkten sein soll, alle Teile ähnlich organisiert, wodurch ihr die Aussicht auf eine grenzenlos wachsende Klassizität eröffnet wird” (Schlegel 1967, 181-182).

The classicistic idea to which Romantic poetry aspired, was that of an orderly and yet dynamic ensemble, in perpetual motion and therefore: "Die romanti- 
sche Dichtart ist noch im Werden; ja das ist ihr eigentliches Wesen, daß sie ewig nur werden, nie vollendet sein kann” (Schlegel 1967, 181-182).

The second passage I propose is the fragment 434, where the romantic poetic utopia of law and dynamism is particularly evident:

\begin{abstract}
Soll denn die Poesie schlechthin eingeteilt sein? oder soll sie die eine und unteilbare bleiben? oder wechseln zwischen Trennung und Verbindung? Die meisten Vorstellungsarten vom poetischen Weltsystem sind noch so roh und kindisch, wie die ältern vom astronomischen vor Kopernikus. Die gewöhnlichen Einteilungen der Poesie sind nur totes Fachwerk für einen beschränkten Horizont. Was einer machen kann, oder was eben gilt, ist die ruhende Erde im Mittelpunkt. Im Universum der Poesie selbst aber ruht nichts, alles wird und verwandelt sich und bewegt sich harmonisch; und auch die Kometen haben unabänderliche Bewegungsgesetze. Ehe sich aber der Lauf dieser Gestirne nicht berechnen, ihre Wiederkunft nicht vorherbestimmen läßt, ist das wahre Weltsystem der Poesie noch nicht entdeckt (Schlegel 1967, 251).
\end{abstract}

When poetry will reveal its secrets and its governing laws will be discovered, then a multiplication of points of view from which to look at reality will finally be possible. Poetry will then be able to offer that multi-perspective gaze with which one could discover truth behind appearances.

In this respect, it is no coincidence that the Jena romantics recognized Cervantes' Don Quijote as the literary antecedent best suited to their new theoretical conception of the novel. Within this book, fiction, i.e. the imaginative delirium of Alonso Quijano, is observed from the side of reality (Sancho Panza's perspective), and conversely reality is observed from the perspective of a chivalric poetic imagery. This multiplication of perspectives has broken down 'mono-logical' poetic constructions, based on unitary visions of the world and their corresponding rhetoric, and has legitimized the mobility of points of view.

The multi-perspectivism of the romantic novel has not remained confined to the literary field but has instead provided the basis of legitimacy for a plural, interdisciplinary approach to knowledge. Its potential for innovation has given rise to manifold critical experiments, through which different sciences have left consistent traces in the discourse of literary criticism.

Typical of this way of understanding culture is, furthermore, the cooperation of disciplines: historiography, for example, is now employing the tools of economics and sociology, in a critical fashion anticipated by the Annales school (Burke 2015). Other significant examples are the current use in literary studies of Darwin's theory of evolution or of cognitive sciences and neuroscience. As an example, a recent study by Michele Cometa offers a detailed review of current studies in the field, mentioned before, of "biopoetics" (Cometa 2017; see also, Cometa 2018). The book, presenting itself as a very useful Forschungsber- 
icht, does not follow an identifiable argumentative line, but rather reviews all major studies that have been published in this field.

Another effect of this type of comparative epistemology is the overcoming of the axiological criterion which establishes what is 'high' and what is 'low'. Studying the form of the fairy tale, Propp discovered that these popular narratives are based on patterns and relationships between the characters which we also find in 'high literature', from Boccaccio's tales to Dostoevsky's novels. "Narrative functions" are thus the original forms of those literary expressions which Jolles would have called 'simple forms', and it is very significative, from the point of view of a modern genealogy of morphology, that Propp begins his Morphology of the Folktale (1928) by quoting a passage from Goethe's studies on morphology (1816-17):

[Morphologie] muß sich als eine besondere Wissenschaft erst legitimieren, indem sie das, was bei andern gelegentlich und zufällig abgehandelt ist, zu ihrem Hauptgegenstande macht, indem sie das, was dort zerstreut ist, sammelt, und einen neuen Standort feststellt, woraus die natürlichen Dinge sich mit Leichtigkeit und Bequemlichkeit betrachten lassen [...]. [D]ie Phänomene, mit denen sie sich beschäftigt [sind] höchst bedeutend [...] und [...] die Operationen des Geistes, wodurch sie die Phänomene zusammenstellt, [sind] der menschlichen Natur angemessen und angenehm [...], so daß auch ein fehlgeschlagener Versuch darin selbst noch Nutzen und Anmut verbinden könnte (Goethe 1981, 127).

Goethe's expectations that morphology would be accepted as a particular science have not yet been fulfilled, as it remains to this day a method that is difficult to define and even more difficult to apply. Nevertheless, it has set in motion some rethinking of the arts' function and statute of autonomy: through morphological studies, for example, it has been shown that the poetic function, as the artistic one, are not actually limited to a purely aesthetic dimension. Conversely, the artistic object could be thought of as an artefact that responds to different needs and in which multiple skills are catalysed, in order to force us to radically rethink aesthetic categories. Such reflections are indicative of a more general trend towards a de- aestheticization of art $^{16}$ which had its precursors already in the Twenties - or rather a re-definition of what aesthetics is; among them Walter Benjamin and his idea of a work that evolves over time in the relationship with its users, and thus loses its 'aura' because of its technical reproducibility (Benjamin 2013).

16 Among the most important studies on this topic one must cite Bredekamp 2010; Danto 2014; Belting 1995. See also Belting 1990. 
As mentioned earlier, Goethe returned in his later years to the study of comparative morphology - begun in 1790 with the publication of the Versuch die Metamorphose der Pflanzen zu erklären. His resurfacing interest in morphological studies took place at the same time as the elaboration of the utopian design of a Weltiteratur, i.e. a global literature born out of the dialogue between different forms, techniques and metaphorical systems and producing poetic outcomes based on the encounters of cultures and on a transnational vision of the arts and of systems of values.

Today in the light of post-colonial studies and an increasing questioning of traditional axiology, this comparison between different literary worlds and its syncretic outcomes gains a renewed topicality or perhaps, for the first time in history, a possibility of realization. In fact, scholars working on literary migrations have already been able to identify numerous examples of contaminations between different literatures: among the many examples, one can think of the case of Gëzim Hajdari, a living Albanian poet who writes epic poems in Italian but recounts the tradition of the Albanian mountain populations and their archaic codes governing the life of these communities (on Hajdari see e.g. Molinarolo 2015, 33-46).

Such experiments are not unusual today and may signal an opening for a new kind of literature, oriented towards a sort of literary syncretism. I would argue that the universality envisaged by Goethe is not likely to be seen in the current context, where narrative literature is dominated by commercial logic and is administered by large publishing groups. Indeed, the drastic reduction of peculiarities, as a by-product of literary globalization, is increasingly common.

At the conclusion of this erratic path in the meanders of morphological thought, it should be stressed that morphology contains two features which philosophical thought has tried to explain since its remote pre-Socratic origins: the stasis of the form and the mobility of the living. If we now observe literary works in the light of these features, we see how the invariant elements can be traced back to the critical environment inspiring the works of Herder, Jakob Grimm, Goethe, and later Warburg and Jolles, and lastly the scholars of biopoetics. Epos and dramatic poetry are thus not only literary genres, originated from Greek models and built in literary tradition, but also, and perhaps above all, basic human inclinations.

This assumption implies that there is a perfect correspondence between the cosmos and the Earth, between the ratio which governs nature and the veritas that, as Augustine contended, lies in interiore homine (Augustine, XXXIX, 72). Finally, we end up with the philosophical constellation of the pre-established harmony theorized by Leibniz, and which leads us to believe that the world, however asymmetrical, disarming and irrational, is built on a plot of references and 
connections concealed to the naked eye, but accessible to an hermeneutics capable of understanding the universal value of the particular. How much this vision, however, is dependent on Greek-Christian optimism and its enchantment is a topic still open to discussion.

\section{Bibliography}

Adorno, Theodor W. (2000): “Form and Matter". In: Metaphysics: Concepts and Problems. Ed. by Rolf Tiedermann. Cambridge: Polity, 60-68.

Augustine of Hippo, De Vera Religione, In: Patrologia Latina. Edited by J.P. Migne. Paris 1841, XXXIX.

Belting, Hans (1990): Bild und Kult: Eine Geschichte des Bildes vor dem Zeitalter der Kunst. München: Beck.

Belting, Hans (1995): Das Ende der Kunstgeschichte: Eine Revision nach zehn Jahren. München: Beck.

Bakhtin, Mikhail (1986): "The Bildungsroman and its Significance in the History of Realism (Toward a Historical Typology of the Novel)". In: Speech Genres and Other Late Essays. Ed. by Caryl Emerson and Michael Holquist. Austin: University of Texas Press, 10-59.

Benjamin, Walter (1978): Briefe, vol. I. Ed. by Gershom Scholem and Theodor W. Adorno. Frankfurt am Main: Suhrkamp.

Benjamin, Walter (1991): “Über den Begriff der Geschichte” 1940. In: Benjamin, Walter: Gesammelte Werke, Band I/2. Frankfurt am Main: Suhrkamp, 690-708.

Benjamin, Walter (2013): Das Kunstwerk im Zeitalter seiner technischen Reproduzierbarkeit [1935-36]. In: Werke und Nachlaß. Kritische Gesamtausgabe, Bd. 16. Frankfurt a. M: Suhrkamp.

Bilstein, Johannes (2004): “Bildung: Über einen altehrwürdigen Grundbegriff und seinen anhaltenden Charme". In: Bildung und Erziehung 57. No. 4, 415-432.

Bing, Gertrud (1965): “A. M. Warburg”. In: Journal of the Warburg and Courtauld Institutes $28,302$.

Boodin, John E. (1943): “The Discovery of Form”. In: Journal of the History of Ideas 4, No. 2, 177-192.

Bredekamp, Horst (2010): Theorie des Bildakts. Frankfurt am Main: Suhrkamp.

Brusotti, Marco - Mainsberger, Sabine (2017): “Kunst des Vergleichens: Warburg, Wittgenstein und die Serendipity morphologischer Reihen". In: Der vergleichende Blick. Formanalyse in Natur- und Kulturwissenschaften. Ed. by Matthias Bruhn and Gerhard Scholz. Berlin: Reimer, 209-238.

Burke, Peter (2015): The French Historical Revolution: The Annales School, 1929-2014. Cambridge: Polity.

Carroll, Joseph (1995): Evolution and Literary Theory. Columbia: University of Missouri Press. Carroll, Joseph (2012): Literary Darwinism: Evolution, Human Nature, and Literature. New York: Routledge.

Catoni, Maria Luisa et al. (2013): Tre figure: Achille, Meleagro e Cristo. Milano: Feltrinelli. Cometa, Michele (2011): "La letteratura necessaria: Sul confine tra letterature ed evoluzione". In: Between 1, No. 1-28. 
Cometa, Michele (2017): Perché le storie ci aiutano a vivere: La letteratura necessaria. Milano: Cortina.

Cometa, Michele (2018): Letteratura e darwinismo: Introduzione alla biopoetica. Roma: Carocci.

Cooke, Brett (2001): “Literary Biopoetics: An Introduction”. In: Interdisciplinary Literary Studies 2. No. 2, 1-8.

Curtius, Robert E. (2013): European Literature and the Latin Middle Ages. Trans. by Willard Trask. Princeton-Oxford: Princeton University Press.

Danto, Arthur (2014): After the End of Art: Contemporary Art and the Pale of History, rev. ed. Princeton: Princeton UP.

Forster, Michael N. (2012): “Bildung bei Herder und Seinen Nachfolgern: Drei Begriffe”. In: Bildung und Freiheit. Ed. by Michael Winkler and Klaus Vieweg. Leiden: Schöningh, 75-89.

Fronterotta, Francesco (2014): “Qu'est-ce qu'une Forme pour Platon? Raisons et fonction de la théorie des intelligibles". In: Lire Platon. Ed. by Luc Brisson. Paris: Presses Universitaires de France, 127-138.

Gaier, Ulrich (2004): “Johann Gottfried Herder (1744-1803), Auch eine Philosophie der Geschichte zur Bildung der Menschheit (1774)". In: KulturPoetik 4. No. 1, 104-115.

Gasser, Andreas (2015): Form und Materie bei Aristoteles. Vorarbeiten zu einer Interpretation der Substanzbücher. Tübingen: Mohr Siebeck.

Gennari, Mario (2014): “La nascita della Bildung”. In: Studi sulla formazione 1, 131-149.

Ginzburg, Carlo (2013): Myths, Emblems and the Historical Method. Baltimore and London: Johns Hopkins.

Goethe, Johann Wolfgang (1981): Goethes Werke (= Münchner Ausgabe), vol. XXVI (Naturwissenschaftliche Schriften I). Ed. by Dorothea Kuhn. München: Beck.

Goethe, Johann Wolfgang (1987): Sämtliche Werke. Briefe, Tagebücher und Gespräche (= Frankfurter Ausgabe), vol. XXIV (Schriften zur Morfologie), ed. by Dorothea Kuhn. Frankfurt am Main: Deutsche Klassiker.

Goethe, Johann Wolfgang (1988): Poetische Werke (= Berliner Ausgabe). Vol. III (Poetische Werke, Gedichte und Singspiele; West-östlicher Divan). Ed. by Siegfried Seidel et al. Berlin: Aufbau.

Goethe, Johann W. (1999): Sämtliche Werke. Briefe, Tagebücher und Gespräche, vol. XXII (Ästhetische Schriften 1824-1832; Über Kunst und Altertum V-VI). Ed. by Anne Bohnenkamp. Frankfurt am Main: Suhrkamp.

Graham, Sarah (ed.) (2019): A History of the Bildungsroman. Cambridge: Cambridge University Press.

Hellmeier, Paul D. (2016): "Bildung im Mittelalter: Albertus Magnus und Meister Eckhart”. In: Münchener Theologische Zeitschrift 67. No. 1, 67-82.

Hennigfeld, Jochem (1984): “Schellings Philosophie der Sprache”. In: Philosophisches Jahrbuch 91. No. 1, 16-29.

Herder, Johann Gottfried von (1772): Abhandlung über den Ursprung der Sprache. Voß: Berlin.

Herder, Johann Gottfried (1774): Auch eine Philosophie der Geschichte zur Bildung der Menschheit. Hartknoch: Riga. 
Heine, Susanne (2016): “Erasmus von Rotterdam und Martin Luther: Erziehung und Bildung an der Grenze zur Neuzeit”. In: Rassegna di pedagogia/Pädagogische Umschau 74. No. 3-4, 455-470.

Horlacher, Rebekka (2017): The Educated Subject and the German Concept of Bildung: A Comparative Cultural History. New York: Routledge.

Jacobs, Jürgen-Krause, Markus (1989): Der deutsche Bildungsroman: Gattungsgeschichte vom 18. bis zum 20. Jahrhundert. München: Beck.

Jolles, André (1968): Einfache Formen: Legende, Sage, Mythe, Rätsel, Spruch, Kasus, Memorabile, Märchen, Witz. Tübingen: Niemeyer.

Koch, Manfred (2002): Weimaraner Weltbewohner: Zur Genese von Goethes Begriff "Weltliteratur". Tübingen: Niemeyer.

Jolles, André (1930): Einfache Formen: Legende, Sage, Mythe, Rätsel, Sprüche. Halle: Niemeyer.

Lemmel, Monika (1987): Poetologie in Goethes west-östlichem Divan. Heidelberg: Winter.

Maatsch, Jonas (ed.) (2014): Morphologie und Moderne. Goethes "anschauliches" Denken in den Geistes- und Kulturwissenschaften seit 1800. Berlin: De Gruyter.

Mayer, Gerhart (1992): Der deutsche Bildungsroman: Von der Aufklärung bis zur Gegenwart. Stuttgart: Metzler.

Molinarolo, Giulia (2015): “Culture in viaggio: I nuovi confini nella letteratura della migrazione in lingua italiana”. In: Levia Gravia 17, 33-46.

Moretti, Franco (1987): The Way of the World: The Bildungsroman in European Culture. London: Verso.

Propp, Vladimir (1968): Morphology of the Tale [1928]. Austin: University of Texas Press.

Propp, Vladimir (1984): Theory and History of Folklore. Minneapolis: University of Minnesota Press.

Propp, Vladimir (1985): Исторические корни волшебной сказки [1946]. It. trans. Le radici storiche dei racconti di fate. Turin: Bollati Boringhieri.

Sbisà, Marina (1984): "Frazer e Wittgenstein: Pathos delle spiegazioni causali e mistica della descrizione fisionomica”. In: La Ricerca Folklorica 10, 33-40.

Schelling, Friedrich W. J. (1989): Werke. Supplementary vol. IV (Persönliches, Nachlaß: 1810-1850). Ed. by Manfred Schröter. München: Beck.

Schlegel, Friedrich Wilhelm Schlegel (1967): Kritische Friedrich-Schlegel-Ausgabe, vol. II (Charakteristiken und Kritiken I. 1796-1801). Ed. by Hans Eichner. Paderborn: Schöningh.

Schwieder, Gabriele (2001): Goethes “West-östlicher Divan”: Eine poetologische Lektüre. Köln: Böhlau.

Schulte, Joachim (1982): “Coro e legge: Il 'metodo morfologico' in Goethe e Wittgenstein”. In: Intersezioni 2. No. 1, 99-124.

Selbmann, Rolf (1994): Der deutsche Bildungsroman. Stuttgart: Metzler.

Settis, Salvatore (1999): Laocoonte: Fama e stile. Roma: Donzelli.

Sorg, Klaus-Dieter (1983): Gebrochene Teleologie. Studien zum Bildungsroman von Goethe bis Thomas Mann. Heidelberg: Winter.

Strich, Fritz (1957): Goethe und die Weltliteratur, 2. ed. Bern: Francke.

Stupperich, Robert (2017): “Im Bereich der Bildung und Erziehung”. In: Stupperich, Robert: Erasmus von Rotterdam und seine Welt. Berlin: De Gruyter, 82-99. 
Swales, Martin (2015): The German Bildungsroman from Wieland to Hesse. Princeton:

Princeton University Press.

Troll, Wilhelm (ed.) (1962): Goethes morphologische Schriften. Jena: Diederichs, 1926.

Vernant, Jean-Pierre (2007): Oeuvres. Religions, rationalités, politique, vol. I. Paris: Seuil.

Vico, Giambattista (2020): The New Science. Ed. by Jason Taylor and Robert Milner. New Haven and London: Yale University Press.

Warburg, Aby (2018a): Florentinische Wirklichkeit und antikisierender Idealismus [1901]. In: Warburg, Aby: Werke. Frankfurt a. M.: Suhrkamp, 211-233.

Warburg, Aby (2018b): Der Eintritt des antikisierenden Idealstiels in die Malerei der Frührenaissance [1914]. In: Warburg, Aby: Werke. Frankfurt a. M.: Suhrkamp, 281-309.

Whistler, Daniel (2013): Schelling's Theory of Symbolic Language: Forming the System of Identity. Oxford: Oxford University Press.

Wieland, Christoph Martin (1981): Geschichte des Agathon. Stuttgart: Reclam.

Wittgenstein, Ludwig - Rhees, Rush (1967): “Bemerkungen über Frazers' The Golden Bough". In: Synthese 17. No. 3, 233-253.

Woodward, William H. (2013): Desiderius Erasmus: concerning the aim and method of education [1904]. Cambridge: Cambridge University Press. 